\title{
SDHD Gene
}

National Cancer Institute

\section{Source}

National Cancer Institute. SDHD Gene. NCI Thesaurus. Code C97779.

This gene plays a role in the localization of succinate dehydrogenase activity. 